Н. Г. Мельник

\title{
ВІДОБРАЖЕННЯ РОЗДУМІВ ПРО ОСОБЛИВОСТІ УКРАЇНСЬКОГО НАЦІОНАЛЬНОГО ХАРАКТЕРУ У ТВОРЧОСТI Т. ШЕВЧЕНКА
}

Мельник Н. Г. Відображення роздумів про особливості українського національного характеру у творчості Т. Шевченка.

У статті розглядаються особливості українського національного характеру, відображені в творах Т. Шевченка «Розрита могила», «Великий льох», «До Основ'яненка», «Стоїть в селі Суботові», «Гайдамаки», «І мертвим і живим», «Прогулка с удовольствием и не без морали». Особливо акцентується на розумінні поетом тісного зв’ язку рис національного характеру українців та їхньої історичної долі.

Ключові слова: національний характер, історія, народ, національний ідеал.

Мельник Н. Г. Отражение размышлений об особенностях украинского национального характера в творчестве Т. Шевченко.

В статье рассматриваются особенности украинского национального характера, отображенные в произведениях Т. Шевченко Розрита могила», «Великий льох», «До Основ’яненка», «Стоїть в селі Суботові», «Гайдамаки», «І мертвим і живим», «Прогулка с удовольствием и не без морали». Особенно акцентируется на понимании поэтом тесной святи черт національного характера украинцев и их исторической судьбы.

Ключевые слова: национальный характер, история, народ, национальный идеал.

Melnyk N. G. Displaying thinking about the features of Ukrainian national character in the works of Taras Shevchenko.

The article deals with the peculiarities of Ukrainian national character reflected in Shevchenko's works: "Dug grave", "The Great Cellar" "To Osnovianenko", "Standing in the village Subotovo","Gajdamaki","For the dead and the living", "Walk with pleasure and 
not without morals". Particular emphasis is placed on poet's understanding of close connection of Ukrainian national character features and their historical destiny.

Key words: national character, the history, the people, the national ideal.

Проблема визначення особливостей національного характеру є сьогодні однією з найперспективніших у гуманітаристиці. На теренах України нагальний інтерес до виокремлення специфічних характерних рис українців, їх відмінностей від представників інших слов'янських народів 3'являється у другій половині XIX століття у зв'язку 3 активним розвитком етнографії та фольклористики. 3 того часу цей інтерес лише посилюється, адже історія українського народу складалася так, що йому повсякчас доводилося відстоювати свою інакшість та право на самостійність.

До проблеми дослідження провідних рис українського національного характеру зверталися в своїх працях В. Антонович, Д. Багалій, Г. Ващенко, М. Грушевський, Д. Донцов, М. Драгоманов, О. Сфименко, М.Костомаров, О.Кульчицький, Ю. Липа, В. Липинський, І.Мірчук, І.Огієнко, Д.Чижевський, М.Шлемкевич, В.Янів та ін.

Важливий внесок у розробку названого напрямку зробили А. Бичко, І. Бичко, В. Горський, Р.Додонов, О. Киричук, С. Кримський, В. Малахов, М. Мокляк, О. Нельга, Ю. Римаренко, В. Храмова, В. Шинкарук та інші. Сучасна дослідниця А. Рубан так визначає поняття «національний характер»: «На світоглядно-філософському рівні національний характер розглядається у феномені ментальності або менталітету, який розкривається у спільній духовно-психологічній орієнтації певної суспільної, насамперед, етно-соціальної групи, що інтегрує потік індивідуальних вражень, уявлень у цілісне світобачення, світовідчуття» [4, с.15].

T. Шевченко, як видатна постать літературного процесу XIX століття, глибокий мислитель, глибоко національний митець, не міг стояти осторонь того наукового руху, що супроводжував діяльність Кирило-Мефодіївського братства. Побратими поета - М. Гулак, М. Костомаров, П. Куліш збагатили науку цілісними дослідженнями й окремими спостереженнями 3 проблеми національного характеру та його зв'язку з історичною долею українців.

У поетичних, прозових творах, щоденникових записах Т. Шевченка також наявні роздуми про позитивні та негативні риси українського характеру. Митець намагається дійти до витоків 
сутності українця, зрозуміти причини тяжкої історичної долі свого народу, утвердити традиційні національні морально-етичні цінності.

У творах Т. Шевченка помітні чіткі пріоритети в оцінці рис українського національного характеру та їх зв'язку з історією народу: $\epsilon$ минула слава, козаччина, що сформували найкращі риси патріотизм, мужність, витривалість, прагнення особистої та національної свободи (особливо це стосується державної еліти); і $є$ сучасна поетові дійсність, що характеризується відсутністю патріотизму, здатністю багатьох земляків до зради національним інтересам, пристосуванством, рабською покірливістю, пошаною до чужих авторитетів, нехтуванням власною культурою, мовою тощо. Отже, у Шевченка, як і в народній творчості, наявний чіткий поділ на минуле і сучасне, що набирають моральної валідності.

Найкращі риси українського національного характеру, на думку Шевченка, залишилися в минулому. У російськомовній повісті «Прогулка с удовольствием и не без морали» автор зазначає: «...моя прекрасная, могучая, вольнолюбивая Украина туго начиняла своїм вольным и вражьим трупом неисчислимые огромные курганы. Она своей славы не потому не давала, ворога-деспота под ноги топтала u, свободная, нерастленная, умирала. Вот что значит могиль $и$ руины. Не напрасно грустны и унылы наши песни, задумчивые земляки мои. Их сложила свобода, а пела тяжкая одинокая неволя» [6, с. 292].

Наскрізною лінією в творах поета проходить думка про наявність в українців чутливості та емоційності. Його герої-чоловіки не соромляться плакати, зокрема й ліричний герой, що сумує над долею України та власною долею: «дивлюся, сміюся, дрібні утираю»; «дивлюсь, поглядаю, сміюся сльозами» [5, с. 63].

У повісті «Прогулка с удовольствием и не без морали» звучать роздуми автора про душевну чистоту, глибоку моральність українців: «O мои милье, непорочне земляки мои! Если бы и материальным добром вы были так богаты, как нравственной сердечной прелестью, вы были бы счастливейший народ в мире! Но увы!! Земля ваша как рай, как сад, насажденный рукою бога-человеколюбия. $A$ вы только безмездные работники в этом плодоносном, роскошном саду. Вы Лазари убогие, питающиеся падающими крупицами от роскошной трапезы ваших прожсорливых ненасытных братий» (виділено нами - Н. М.) [6, с. 293].

У цьому ж творі письменник вказує на таку рису українського характеру, як наполегливість: «...уж если что мне раз пришло в 
голову, хотя бы самое несбыточное, так хоть роди, а подавай. На этом пункте я имею большое сходство с моими неподатливими земляками. Писатели наши и вообще люди приличные чувство это называют силою воли; а его просто можно назвать вольным упрямством. Оно живописне и выразительнее [6, с. 226].

Глибоке захоплення T. Шевченка народною творчістю, досконалістю змісту і форми творів, звучить у словах: «Недавно кто-то печатно сравнивал наши, т.е. малороссийские, исторические думь с рапсодиями хиосского слепща, праотща эпической поэзии...Я читал, разумеется, в переводе Гнедича, и вычитал, что у Гомера ничего нт похожого на наши исторические думь-эпопеи, как например «Иван Коновченко», "Савва Чальй», "Алексей, попович пирятинский», или «Побег трех ьратьев из Азова», или «Самойло Кишка», или, или, - да их и не перечтешь. И все они так возвышенно просты и прекрасны, что если бы воскрес слепец хиосский да прослушал хоть одну из них от такого же, как и сам он, слепча кобзаря или лирныка, то раз бил бы вдребезги свое лукошео, называемое лирой, и поступил бы в михоноши к самому бедному нашому лирныку, назвавии себя публично дурнем» [6, с. 265].

Автор відзначає наявність у народу невмирущого почуття гумору, що виявляється навіть у трагічних обставинах. Як легендарний Байда 3 відомої пісні перед лицем смерті, його герої демонструють моральну перевагу над своїми ворогами : «Земляки мои, в том числе и я, самую серьезную материю не когут не проткать хоть слегка, хоть едва заметной шуточкой. Земляк мой (разумеется, невольно) в потрясаючий финал «Гамлета» всучил такое слово, что сквозь слезы ульбнешься. В доказательство я приведу пример исторический. Сообщники Искрі и Кочубея поп NN и писар Подобайло, после доброй питки кнутом лежали окровавленные на полу под. рогожею и рассуждали о том, что не мешало бы позычить у москаля кропила (кнута) для своих непослушных жен. Не правда ли, на своем месте шуточка?» [6, с. 326].

Натомість Шевченко гостро засуджує довірливість, недалекоглядність, невиправдану миролюбність, що часто не дає змоги українцеві розпізнати в інших (чужих) підступність та хитрість (поеми «Великий льох», «Розрита могила»). Так, у поемі «Великий льох» через образи трьох проклятих душ автор розкриває причини трагедій національного масштабу.

Одна душа, будучи людиною, перейшла 3 повним відром гетьману Богдану Хмельницькому шлях, коли той їхав на 
Переяславську раду. Після цього невільного злочину вода у відрі стає отруйною і гине вся родина. На думку Шевченка, так карає Бог за зраду: І вже ледви я наледви / Донесла до хати - / Оту воду... Чом я з нею / Відер не побила! / Батька, матір, себе, брата, / Собак отруїла / Тією клятою водою [5, с. 212].

Друга душа карається за те, що напоїла коня цареві Петру, коли той їхав до Москви. Автор акцентує увагу на тому, що цей вчинок дівчина робить після того, як зазнала знущань із боку москалів, стала свідком численних вбивств під час розправи Петра після поразки Мазепи під Полтавою: Я була щуе недолітком, / Як Батурин славний / Москва вночі запалила, / Чечеля убила, / I малого, i старого / В Сейму потопила. Я меж трупами валялась / $У$ самих палатах Мазепиних...Коло мене / I сестра, і мати / Зарізані, обнявшися, / 3 о мною лежали; / I насилу-то, насилу / Мене одірвали / Од матері неживої. / Що вже я просила / Московського копитана, / Щоб і мене вбили. / Ні, не вбили, а пустили / Москалям на грище! [5, с. 213].

Після цього гріховного вчинку дівчина вмирає на порозі хати, а душа іï проклята Богом: I за щзо мене карають, / Я й сама не знаю? / Мабуть за те, щио всякому / Служила, годила.../ Що цареві московському / Коня напоӥла!.. (виділено нами - Н. М. ) [5, с. 213].

Третя душа проклята за те, що, будучи малою дитиною, усміхнулася цариці Катерині, яка пропливала по Дніпру: Ось за щз, мої сетриці, / Я тепер караюсь, / За щзо мене на митарство / Й досі не пускають. / Чи я знала, ще сповита, / Що тая цуариия - /Лютий ворог Украйни, /Голодна вовчиця!.. (виділено нами - Н. М. ) [5, с. 214].

На думку автора, такі риси, як довірливість, рабська покірність, здатність прислужувати кожному, відсутність почуття національної гідності - це не лише негативні риси українського характеру, а й великий гріх, хоч і вчинений ненавмисно, через нерозуміння. Цей гріх має бути покараний вищим судом, при чому смерть - миттєва.

Отже, прислужництво, дезорієнтованість у політичних подіях оцінюються Шевченком як богопротивні риси.

Доля України осмислюється поетом через образи матері, залишеної, зрадженої власними дітьми, вдови, сироти. У поемі «Розрита могила» Україна звертається до Богдана Хмельницького. У іiі словах - глибокий аналіз результатів недалекоглядності і довірливості гетьмана: Ой Богдане, Богданочку! / Якби була знала, / У колисиі б задушила, / Під серием приспала. / Степи мої запродані / Жидові, 
німоті, / Сини мої на чужині, / На чужій роботі. / Дніпро, брат мій, висихає, / Мене покидає. / I могили мої милі / Москаль розриває... / Нехай риє, розкопує, / Не своє шукає. / А тим часом перевертні. / Нехай підростають / Та поможуть москалеві / Господарювати, / Та в матері полатану / Сорочку знімати [5, с. 164].

Роздуми про комплекс меншовартості, притаманний українцям, наявні у творах «До Основ'яненка», «Гайдамаки», «Стоїть в селі Суботові», «І мертвим і живим...»У Вірші «До Основ'яненка» поет фактично передає стан людини, яка, перебуваючи в чужомовному, інонаціональному оточенні, втрачає здатність відстоювати національну гідність та обирає мовчання: Чи правду співаю? / Ex, якби-то...Той щчо казать? / Кебети не маю. / $А$ до того Московщина, / Кругом чужі люде. / «Не потурай», -може, скажеш, / Та щзо з того буде? / Насміються на псалом той, / Що виллю сльозами; / Насміються...Тяжко, батьку, / Жити з ворогами! / Поборовся б і я, може, / Якби малось сили; заспівав би - був голосок, / Та позички з'їл (виділено нами - Н. М.) [5, с. 55-56].

У поемі «Гайдамаки» звучать слова: Сини мої! Орли мої! / Летіть 8 Украйну, / Хоч і лихо зустрінеться, / Так не на чужсині. / Там найдеться душа щира, / Не дасть погибати / A тут...а тут...тяжкко, діти! / Коли пустять в хату, / То, зустрівии, насміються, - / Такі, бачте, люди: / Все письменні, друковані... (виділено нами - Н. М.) [5, с. 61].

У поезії «Стоїть в селі Суботові» звучить думка про те, що помилкові політичні рішення державної еліти, байдужість до долі батьківщини призводять до того, що «сміються жс з Украӥни стороннії люди» (виділено нами - Н. М. ): Сміються, не розуміють: / «Не смійтеся, чужі люде!» / Церков-домовина / Розвалиться.. і з-під неї / Встане Украӥна! / I розвіс тьму неволі, / Світ правди засвітить, / I помоляться на волі / Невольничі діти [5, с. 223].

Апофеозом роздумів Шевченка про негативні риси національного характеру українців $є$ поема «І мертвим, і живим...». Ліричний герой звертається до своїх земляків із вимогою усвідомити відповідальність за зрадництво, нехтування інтересами народу, пристосуванство, байдуже ставлення до рідної культури: Схаменіться, недолюди, / Діти юродиві! / Подивіться на рай тихий, / На свою краӥну, / Полюбіте щиирим серием / Велику руїну, / Розкуйтеся, братайтеся! / У чужому краю не питайте / Того, щзо немає / I на небі, а не тілько / На чужому полі. / В своїй хаті своя й правда, і сила, і воля [5, с. 240]. 
Отже, результати дослідження дають змогу зробити висновок про постійний інтерес Т. Шевченка до проблеми українського національного характеру, що певною мірою визначив хід історії народу. Маючи тонку, чутливу, вразливу душу, щирий та довірливий українець часто наражається на хитрість та підступність ворогів (чужих людей). Маючи славну історію, нащадки козацьких ватажків (державна еліта), на думку Шевченка, не завжди є продовжувачами героїчних традицій. Навпаки, вони або пристосовуються до умов рабського існування або відкрито зраджують національним інтересам заради особистої вигоди. Мотив матері, зрадженої дітьми; образи невдячних синів; «правнуків поганих», «перевертнів»- провідні в Шевченка.

Г. Семенюк зазначає: «Національна і політична самостійність України - це головний і незмінний ідеал Шевченка впродовж всієї його творчості. Звідси ідеалізація (в позитивному сенсі слова) гетьманів, ватажків національно-визвольних змагань, які виборювали свободу Україні: Гонти й Залізняка («Гайдамаки»), «Дорошенка»(«Заступила чорна хмара»), Полуботка («Сон»), Гордієнка («Іржавець»), і зневага, погорда і ненависть до тих, хто свідомо чи підсвідомо зраджував Україну, поневолював іiі; хто задля своїх амбіцій та інтересів здійснював політику розчленування України, хто шляхом приниження, плазування, ціною свободи всього народу здобував гетьманську булаву, дворянські титули, маєтки» [2, с. 334].

Відповідно, митець акцентує на необхідності усвідомлення українцями відповідальності за подальшу долю батьківщини, глибокого аналізу помилок минулого та вірить у щасливе майбутнє України.

\section{Література}

1.Історія української літератури (20-40-ві роки XIX століття) : [підручник] / [за ред. проф. Г.Ф. Семенюка]. - К. : Видавничо-поліграфічний центр «Київський університет», 2009. - 384 с.

2.Історія української літератури XIX століття : у 2-х кн. Кн.1 : [підручник] / [за ред. акад. М. Г. Жулинського]. - К. : Либідь, 2005. - 656 с.

3.Рубан А. О. Світоглядні особливості українського національного характеру (філософсько-антропологічний аналіз : автореф. дис. ... канд. філос. наук / А. О. Рубан. - К, 2008. -20 c.

4.Шевченко Т. Г. Кобзар / Тарас Григорович Шевченко / [авт. вступ. ст. О. Гончар]. - К. : Дніпро, 1989. - 541 с.

5.Шевченко Т. Г. Прогулка с удовольствием и не без морали / Тарас Григорович Шевченко / Шевченко Т. Г. Твори : у 5-и т. Т.4 ; приміт. В. Бородіна. - К. : Дніпро, 1985. - C. 226-359.

Стаття надійшла до редакиії 12.11.2014 p. 